\title{
БИОМЕДИЦИНСКИЙ КЛЕТОЧНЫЙ ПРОДУКТ В ЛЕЧЕНИИ ПОВРЕЖДЕНИЙ КОЖИ
}

\author{
1,2Лыков А.П., ${ }^{1,2}$ Суровцева М.А., ${ }^{1.2}$ Бондаренко Н.А., ${ }^{1,2}$ Ким И.И, ${ }^{1,2}$ Повещенко О.В. \\ ${ }^{1}$ НИИКЭЛ-филиал ИЦИГ СО РАН, Новосибирск, Россия \\ гНМИЦ им. акад. Е.Н. Мешалкина МЗ РФ, Новосибирск, Россия
}

Дефекты кожных покровов, возникающие при ожогах, патологии периферических сосудов, синдроме диабетической стопы требуют длительного и дорогостоящего лечения и часто традиционные способы лечения недостаточны для достижения полной эпителизации раневых дефектов. Перспективным способом лечения дефектов кожных покровов рассматривается внедрение достижений в области клеточных технологий, включая мезенхимные стволовые клетки (МСК), кондиционные среды мезенхимных стволовых клеток (КС-МСК), лизат тромбоцитов (ЛТ).

ЦЕЛЬ: сравнительный анализ терапевтического потенциала биомедицинского клеточного продукта при раневых дефектах кожных покровов различного генеза.

МАТЕРИАЛЫ И МЕТОДЫ: Исследование проведено на животных и больных трофическими язвами сосудистого генеза и при синдроме диабетической стопы. У мышей С57BI6 с стрептозотоцин-индуцированным сахарным диабетом и без стрептозотоцин-индуцированного сахарного диабета моделировали ожог кожи в области спины, далее по периметру дефекта кожи вводили 10\%/0,2 мл физиологического раствора МСК или 0,2 мл КС-МСК однократно. Эффективность лечения биомедицинским клеточным продуктом оценивали по динамике эпителизации раневого дефекта и гистологической картине в области раневого дефекта. MCK получали из костного мозга бедренных костей культивированием в среде DMEM с добавлением 10\% FCS, 2 мM L-глутамина, 5 мM Hepes-буфера и 80 мкг/мл гентамицина. B работе использованы MCK 4-го пассажа. KC-MCK собирали от МСК 3-го пассажа. Сахарный диабет у мышей С57BI6 индуцировали внутрибрюшинным введением стрептозотоцина (60 мг/кг). У 19 больных с синдромом диабетической стопы (СДС) и 11 больных с трофическими язвами сосудистого генеза (ТЯ) забирали периферическую венозную кровь в специализированные пробирки для Плазмолифтинга для получения обогащенной тромбоцитами плазмы. Обогащенную тромбоцитами плазму получали осаждением на центрифуге при 3800 оборотов в минуту в течение 8 минут, собирали надосадочную плазму и далее повторно осаждали при 3500 оборотов в минуту в течение 15 минут. Надосадочную плазму переносили в стерильную пробирку, осадок (обогащенная фракция тромбоцитов) в 1 мл плазмы подвергали циклам заморозки/разморозки для разрушения целостности мембран клеток и выхода содержимого в плазму, далее фильтровали через миллипоровые насадки и смешивали с оставшимся объемом плазмы - на выходе лизат тромбоцитов. После хирургической обработки дефектов кожи больным по периметру язв вводили 3-4 мл ЛТ дважды с интервалом 5-7 дней, эффективность лечения оценивали по эпителизации раневого дефекта.

PЕзУЛЬТАТЫ: введение МСК или КС-МСК мышам с ожогом на фоне сахарного диабета или же без сахарного диабета ускоряет эпителизацию ожоговой раны по сравнению с контрольными мышами, не получавшими лечения биомедицинским клеточным продуктам ( $<<0.05)$. Введение биомедицинского клеточного продукта стимулирует восстановление волосяных фолликулов, жировых желез и сосудов, питающих дерму по данным гистологического исследования в сравнении с контрольными группами ( $<<0.05)$. Введение ЛТ по периметру язвенных дефектов кожи у больных с СДС и ТЯ способствовало ускорению процесса эпителизации раневого дефекта по сравнению с контрольными группами, получавшими традиционное лечение.

Выводы: биомедицинский клеточный продукт ускоряет репарацию/регенерацию дефектов кожных покровов. 